\title{
The Role of Culture on SME Access to Credit: Implications for Developing Nations
}

\author{
Enoch Kusi Asare \\ University of Dallas \\ Joseph Nketia \\ St. Edwards University \\ Sri Beldona \\ University of Dallas \\ Scott Wysong \\ University of Dallas
}

The literature suggests that small and medium-sized enterprises (SMES) are critical to the advancement of developing economies. Yet, SMEs in developing nations are constrained with capital accessibility, which is complicated by societal values (culture). In this paper, we examine the impact of culture (as a moderating variable) on firm size and funding source (independent variables) with regard to access to capital (dependent variable) by looking at 2,185 SMEs from 27 developing economies. Our results indicate that state-owned banks, set up with the objective of providing capital to SMEs in developing economies, have not lived up to expectations. Governments of developing economies should put mechanisms in place to address this challenge.

Keywords: small and medium-sized enterprises (SMEs), access to capital, firm size, funding source, Hofstede's cultural dimensions

\section{INTRODUCTION}

Although small and medium-sized enterprise (SMEs) form the bedrock of developing economies, they face numerous financing challenges (Asare et al. 2020, Chai et al. 2019, Chand and Parmar 2018, Afrifa and Tingbani, Neagu 2016, Beck et al. 2005, Beck et al. 2008). Critical determinants such as availability of audited financial statements, firm size, funding source, banking relationship, collateral, credit scores, cultural factors, etc. impact their financing (O'Donohoe et al. 2008, Dong and Men 2014, Asare et al. 2020, Wellalage et al. 2019, Berger and Udell 2006). Although these challenges are global, they are more pronounced in developing nations. For example, audited financial statements are almost nonexistent among SMEs in developing and emerging economies (Wellalage and Locke 2016, Wellalage et al. 2019, Dong and Men 2014). Similarly, the complex credit scoring modules that lenders in advanced economies use to 
determine loan default risks are not available in most developing countries due to information opacity (Asare et al. 2020, Distinguin et al. 2010).

Moreover, societal values such as individualism, collectivism, uncertainty avoidance, and power distance can further impact lender and borrower behaviors at the individual and national levels. Despite the importance of these cultural factors, cross-cultural studies on SME financing among developing nations have not received much attention in the accounting literature. While the entrepreneurship literature has tried to shed some light on this issue, the focus has been on individual economies, with less emphasis on crosscultural studies (Berger et al. 1998, Berger and Udell 2006, Beck et al. 2005, Beck et al. 2008, Wellalage and Locke 2016, Wellalage et al. 2019). In this paper, we examine the impact of culture on two determinants of SME access to financing in developing nations: SME firm size and funding source.

To investigate this, we analyzed the impact of firm size on SME access to financing from the perspective of the cost versus benefit of disclosing pertinent firm-specific information (Ogden and Clarke 2005, Verrecchia 1999, Cheng et al. 2013). That is, ceteris paribus, larger organizations usually have the means of providing quality and credible information about their businesses, placing them in a better position to access financing. The concept of cost versus benefit of disclosing pertinent financial information is a well-grounded concept of analyzing credit worthiness in developed economies, which are often more individualistic cultures. However, the concept has not been well-studied in developing and emerging economies, which are often more collectivistic.

We also analyzed the impact of funding sources from the social and agency views of state-owned enterprises (SOEs) (Hart et al. 1997, Banjeree 1997, Atkinson and Stiglitz 1980). According to the social view of SOEs (public banks), SOEs can buffer shocks in economic development by addressing market failures when corresponding social benefits exceed costs (Atkinson and Stiglitz 1980, Sapienza 2004). From this perspective, we view public banks as SOEs created by states to provide financing to SMEs to foster economic development. Thus, everything being equal, public banks are expected to make financing more accessible to SMEs compared to private banks. On the other hand, the agency view perceives SOEs as institutions that were created to benefit the public, but that can be susceptible to corruption (Hart et al. 1997, Banjeree 1997, Sapienza 2004). From this perspective, bureaucracies in SOEs can result in the misapplication of state-owned assets due to weak internal managerial controls (Tirole 1994, Sapienza 2004). The social and agency views of SOEs have been widely discussed in the economics and politics literature, but the cultural impacts of the social and agency views from the perspectives of SME financing is largely absent in the accounting literature.

The objective of this study is to answer the following research question: For a given SME size and funding source in a developing economy, does the cultural environment influence access to financing? This research question is critical to enhancing our understanding of the dynamics of the determinants of SME access to credit in developing nations (Berger and Udell 2006, Dong and Men 2014, Asare et al. 2020). Over the last couple of decades, the SME financing literature has paid a great deal of attention to the drivers of SME access to financing in local cultural environments. But, there has been little, if any, research when it comes to cross-cultural comparisons of SME access to capital in developing economies.

Berger et al. (1998) examined the impact of mergers and acquisitions on small business lending, but they focused solely on the United States. Berger and Udell (2006) proposed a framework of SME lending strategies that acknowledges the importance of culture. Their framework included financial statements, SME credit scoring, assets, leasing, relationships, trade-credit, funding source, market competition, culture, legal, and regulatory environments as important influencers of SME financing. Since Berger and Udell's (2006) work, several studies have given attention to the relationships between these SME financing factors and access to credit, yet with little focus on cross-cultural impacts (Afrifa and Tingbani 2018, Chand and Parmar 2018, Chai et al. 2019, Wellalage and Locke 2016, Wellalage et al., 2019).

While understanding the drivers of SME funding decisions in local cultural environments is critical, it is equally important to understand how these funding decisions vary across cultures (Chai et al. 2019, Asare et al. 2020, Wellalage et al. 2019, Wellalage and Locke 2016). A number of studies in the accounting and finance literature suggest that culture is a critical player in business accounting and finance (Chow et al. 1995, Arnold et al. 2005, Kanagaretnam et al. 2011; Kanagaretnam et al. 2014, Bell et al. 2012, Asare et 
al. 2020, Han et al. 2010, Salter et al. 2013, Gu et al. 2019). In an analysis of banks from 39 countries, Kanagaretnam et al. (2011) found that banks in certain cultures are willing to take on more risk in loan underwriting than similar banks in other cultures. Consistent with this finding, Kanagaretnam et al. (2014) concluded that national culture influences bank lending and risk-taking behavior in a cross-country analysis of bank lending behavior. Similarly, Han et al. (2010) document that national culture influences capital markets, which ultimately impact bank lending behavior. National culture also influences accounting values, which in turn influence bank lending behavior (Bentley and Franklin 2013, Asare et al. 2020). Gu et al., (2019) and Bell et al., (2012) document that the national culture in which the firm operates can be a liability in its attempt to access foreign capital. Although these studies provide a rich understanding of the impact of culture on borrower access to capital, they largely focus on large firms in advanced economies with little emphasis on SMEs in developing economies.

Focusing on SMEs in developing economies is necessary because they are the economic backbone of these countries (Berger and Udell 2002, Chai et al. 2019, Chhabra and Pattanayak 2014, Wellalage et al. 2019, Wellalage and Locke 2016). In fact, SMEs account for over $90 \%$ of all businesses in most developing economies and empower economic development through innovation and the production of goods and services (Okafor 2012). Moreover, in economic juggernauts such as China and India, SMEs are abundant. For example, China has about 40 million SMEs, which account for 50\% of Chinese gross domestic product (GDP), about $40 \%$ of national revenue, and over $70 \%$ of all Chinese jobs (Wu et al. 2008, Chai et al. 2019). In India, SMEs play a critical role in their economy, as well, (Chand and Parmar 2018) with over 48 million SMEs, accounting for about $90 \%$ of the country's industries, and about $17 \%$ of GDP (Rao et al. 2019). Similarly, SMEs are critical to the economies of Mexico, South America, and Africa, spearheading jobs and economic growth (Madill et al. 2002, Angeles et al. 2019, Parnell 2015, Okafor 2012, Haselip et al. 2013).

Given the importance of SMEs to developing economies, we examined the impact of culture on SME financing in these economies, using Hofstede's (1983) cultural dimensions, which have been found to be robust across many cultures over time. The accounting literature, in particular, has assessed the impact of culture utilizing Hofstede's cultural dimensions of individualism/collectivism (IDV), power distance (PDI), and uncertainty avoidance index (UAI) as proxies (Hope 2003, Hope et al. 2013; Salter and Niswander 1995, Salter et al. 2013, Tsakumis 2007, Kanagaretnam et al. 2014, Asare et al. 2020, Bentley and Franklin 2013). Each of these cultural dimensions will be discussed in future sections of the paper.

\section{LITERATURE REVIEW AND HYPOTHESES}

\section{Firm Size}

Extant literature has looked at how firm size is key in enabling organizations to gain access to financial markets (Beck et al. 2005, Beck et al. 2008, Baiman et al. 2010, Sharifi 2014, Xiao and North 2012). In addition, the primary mechanism for minimizing the risk associated with an organization's ability to pay its debt is the availability of audited financial statements (Asare et al. 2020, Verrecchia 1999, Armstrong et al. 2011, Baiman et al. 1996). Compared to smaller organizations, larger firms have the ability to hire large international auditing firms to audit their financial statements, and thus establish credibility, making large organizations more creditworthy than smaller ones (Angori et al. 2019, Emett 2019, Darrough and Deng 2019, Huang et al. 2015, Kira and He 2012).

Using a firm-level survey database covering 54 countries, Beck et al. (2005) found that small businesses are constantly constrained with financial obstacles. In fact, the authors found that larger firms were better able to access external financing than smaller firms, even when the larger firms were constrained. Moreover, Thiaw (2019) identified only a few SMEs that applied for loans in the West African region that won approval. Many of the SMEs that were rejected had poor record-keeping, a low credit standing, and the inability to substantiate creditworthiness. And, this trend is consistent across all regions of the world (Sharifi 2014, Kuntchev et al. 2013, Yang et al. 2013, Luo et al. 2016, Audretsch 2002, Parnell 2015, Berger et al. 2001). Conversely, larger businesses are able to produce relevant audited documents, which help them gain 
access to financing (Barron and Hong 2014, Hail and Serafeim 2011, Bertomeu and Cheynel 2013, Chen et al. 2015).

Based on this literature, we expect that as firm size increases, their ability to disclose and substantiate better information to lenders increases, resulting in higher access to financing. Thus, it is hypothesized;

H1: Compared to smaller SMEs, larger size SMEs in developing economies are more likely to gain access to financing.

\section{Funding Source}

Due to the difficulty in gaining access to financing, private and state-owned banks have developed a myriad of funding programs to allow them to provide funds to SMEs (Beck et al. 2011, Berger and Udell 2006, Berger and Udell 1988). For instance, almost all banks in Africa, Asia, Europe, and the Americas have divisions specifically designed to serve SMEs (Okafor 2012, Berger and Udell 2006, Parnell 2015, Chai et al. 2019, Rao et al. 2019). In addition to banks, other financing institutions such as venture capitalists, microfinance schemes and crowdfunding provide financing to SMEs (Mollick 2014, Belleflame et al. 2014, Belleflame et al. 2013, Chai et al. 2019, Pollack et al. 2012). While venture capital and crowdfunding are promising sources of financing for SMEs, they are not very prevalent in developing economies. (Blaseg and Koetter 2015, Agrawal et al. 2011, Davidson et al. 2013). This leaves banks and microfinancing schemes as the primary sources of funding for SMEs in developing economies.

Within the banking industry, there are state-owned and private banks that serve the SME markets (Saparito et al. 2004, Amidu et al. 2011, Berger and Udell 2002). State-owned banks are owned by the government to promote the development of business to boost the economy (Bisman and Goela 2010, Sharifi 2014, Okafor 2012). Conversely, private banks are owned by individuals or shareholders and provide banking services to firms and individuals. Previous researchers have concluded that state banks are primarily established to provide financing to SMEs (Saparito et al. 2004, Chai et al. 2019, Audretsch 2002). In addition, Sapienza (2004) found that there are relatively more state-owned banks than private banks in developing economies, and that state-owned banks hold the majority of capital in most of these economies (Sapienza 2004). Thus, state-owned banks usually offer relatively lower interest rates and favorable financing terms to their borrowers, supporting the agency and social views of state-owned enterprises (SOEs).

However, due to corruption (Elamer et al. 2019) and political biases in developing economies, stateowned banks often end up favoring larger and state-owned businesses to the detriment of SMEs (Wellalage et al. 2019; Hoang and Phung 2019, Sapienza 2004). From an analysis of banks across Italy, Sapienza (2004) found that state-owned banks do not lend to SMEs as much as one would expect due to corruption and political reasons. Wellalage et al. (2019) also found that corruption decreased access to financing in South Asian SMEs by as much as 7.63\%. Lastly, in a study of over 4,000 banks across 56 countries, Barth et al. (2009) found that state-owned banks were more likely to be influenced by corruption compared to private banks. Barry et al. (2017) came to a similar conclusion.

Given the literature, we would expect that most SMEs seek funding from private banks rather than from state-owned banks. Thus, it is hypothesized;

H2: SMEs in developing economies are more likely to seek financing from private banks (than state-owned banks).

\section{The Impact of Culture}

Individualistic Versus Collectivistic Cultures

According to Hofstede and Bond (1988), "Individualism is the extent to which members of society look out for the interests of themselves and those of their immediate family members" (Hofstede and Bond 1988, p. 11). That is, in high individualistic societies, members are conditioned to fend for themselves instead of the society at large. In contrast, in low individualistic (or collectivistic) societies, members of the society rely on in-group memberships for protection and other benefits (Hofstede and Bond 1988). Researchers 
have also found that individualism influences banks' propensity to aggressively lend to borrowers through risk-taking and earnings management (Kanagaretnam et al. 2011, Kanagaretnam et al. 2014, Asare et al. 2020). In high individualistic cultures, bankers tend to fend for themselves rather than for the bank, and thus, they are often much more daring and aggressive when underwriting loans, compared to bankers in collectivist cultures (Kanagaretnam et al. 2011, Kanagaretnam et al. 2014). On the other hand, borrowers in individualistic societies are more transparent and disclose more information about their business. Taken together, the aggressive lending behaviors of banks and the transparency of firms (based on size) favor credit accessibility among borrowers in highly individualistic cultures (Asare et al. 2020). Similarly, Kanagaretnam et al. (2014) found that compared to collectivist cultures, individualistic cultures are more favorable towards credit and financing accessibility.

In summary, holding SME size and funding source constant, we expect SMEs in developing economies to have more access to financing in high individualistic cultures, compared to low individualistic cultures. Thus, it is hypothesized;

H3a: The relationship between SME size and access to financing in developing economies will be stronger (weaker) in high (low) individualistic cultures.

H3b: The relationship between SME funding source and access to financing in developing economies will be stronger (weaker) in high (low) individualistic cultures.

\section{Uncertainty Avoidance Cultures}

Uncertainty avoidance is "the extent to which members of a society feel uncomfortable about ambiguities" as defined by Hofstede and Bond (1988, p. 11). Members of high uncertainty avoidance societies are prone to minimize risk-taking to avoid future uncertainties (Hofstede and Bond 1988). That is, members of these high uncertainty avoidance societies are more risk-averse and have lower acceptance for ambiguities (Zheng et al. 2013). Given their low tolerance for the vague or unknown, members in high uncertainty avoidance cultures express their frustrations in emotions, anxiety, and stress (Hofstede 1983). Therefore, borrowers in high uncertainty avoidance cultures are usually more conservative and have fewer incentives to aggressively seek bank financing. Additionally, to minimize uncertainties, borrowers in high uncertainty avoidance cultures tend to be secretive and disclose less information to lenders (Asare et al. 2020, Bentley and Franklin 2013, Salter et al. 2013).

Also, uncertainty avoidance has been shown to impact bank lending behavior. In high uncertainty avoidance cultures, lenders often minimize ambiguities, and thus, are more conservative (Kanagaretnam et al. 2011, Bentley and Franklin 2013, Kanagaretnam et al. 2014). To this end, bankers can be less daring and aggressive when underwriting loans, giving them fewer incentives to manage earnings to declare large profits (Kanagaretnam et al. 2014). That is, lenders are more conservative in recognizing earnings and less transparent (more secretive) in reporting income (Kanagaretnam et al. 2014). Additionally, due to the low tolerance for uncertainty, lenders are less likely to manage their earnings to meet or exceed prior year numbers (Braun and Rodriguez 2008, Kanagaretnam et al. 2011). This high uncertainty avoidance translates to more anxiety, less accuracy in future projections (Sharma 2009) and less risk-taking on the part of lenders (Kanagaretnam et al. 2014).

In summary, holding SME size and funding source constant, we expect uncertainty avoidance behaviors to limit credit accessibility to SMEs in developing economies. Thus, it is hypothesized;

H4a: The relationship between SME size and access to financing in developing economies will be weaker (stronger) in high (low) uncertainty avoidance cultures.

H4b: The relationship between SME funding source and access to financing in developing economies will be weaker (stronger) in high (low) uncertainty avoidance cultures. 


\section{Power Distance Cultures}

As Hofstede and Bond (1988) outlined, "Power distance is the extent to which members of society believe that power should be shared unequally among members in the society" (Hofstede and Bond 1988, p. 10). That is, members in high power distance cultures are taught to accept that certain members of the society (e.g., bosses, the elderly, and leaders) ought to be treated with respect, and in some instances, their authority should not be questioned. In this regard, we expect SMEs in high power distance cultures to follow along with the demands of their leaders. These demands could be in the form of disclosing more or less information to lenders.

As with borrower behavior, power distance affects bank lending behavior. Extant literature shows that members in high power distance societies are aggressive in borrowing and earnings management (Braun and Rodriguez 2008, Kanagaretnam et al. 2011). Conversely, lenders in low power distance societies have been found to be less enthusiastic about managing their earnings to declare higher profits. We expect this disincentive to manage earnings to result in rigorous financing underwriting standards among banks in low power distance cultures with corresponding lower access to credit. Thus, it is hypothesized;

H5a: The relationship between SME size and access to financing in developing economies will be stronger (weaker) in high (low) power distance cultures.

H5b: The relationship between SME funding source and access to financing in developing economies will be stronger (weaker) in high (low) power distance cultures.

Figure 1 portrays the relationships that are examined in this research. As illustrated, we hypothesize that SME firm size and funding source in developing economies should each have a direct effect on SME access to financing. In addition, we believe that cultural dimensions such as individualism, uncertainty avoidance, and power distance should moderate these relationships. How we plan to test the relationships outlined in Figure 1 will be discussed in the next section.

\section{FIGURE 1 \\ RELATIONSHIPS BEING EXAMINED IN THE STUDY}

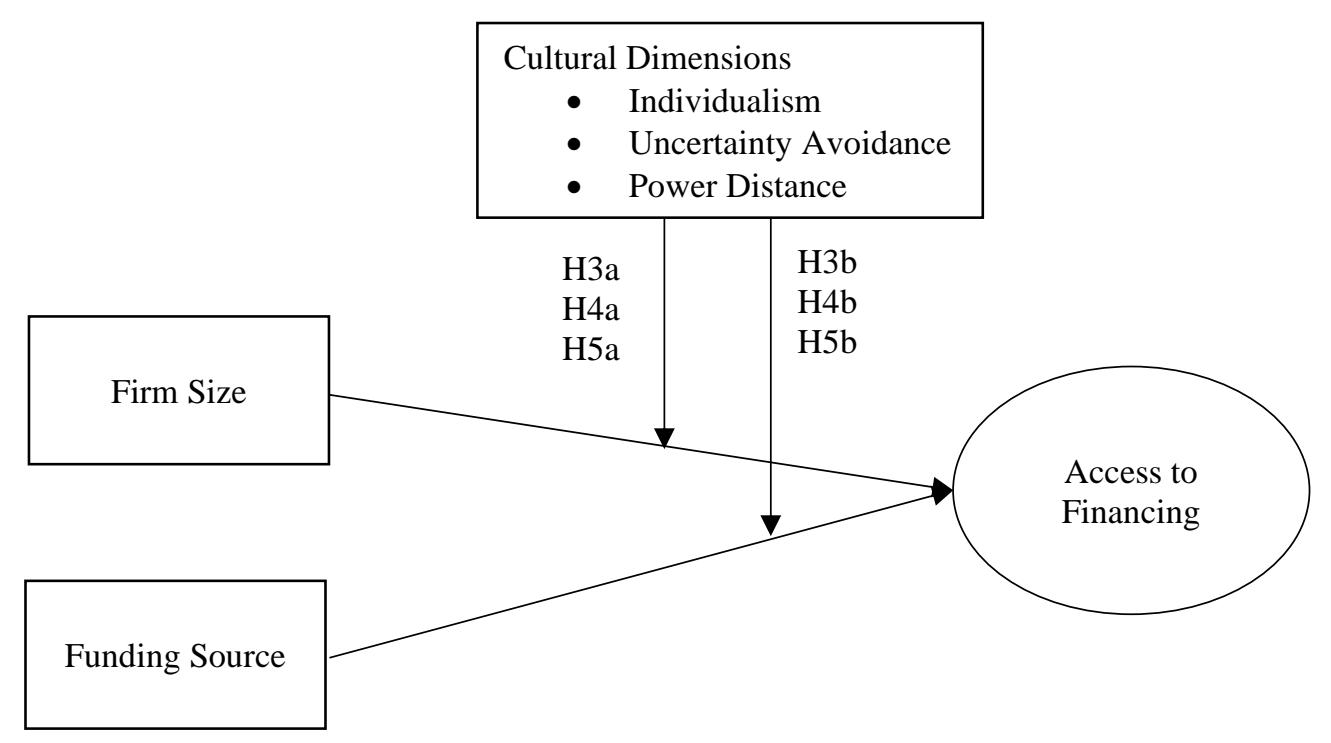




\section{METHODOLOGY}

\section{Sample and Data Description}

The data for this research is comprised of firm-level enterprise surveys from developing economies, conducted by the World Bank between 2006 and 2019. After cleaning the data to address missing data issues and unavailability of Hofstede country dimensions, the final sample size was 2,185 SMEs from 27 countries. Industries represented in the sample include metals, chemicals, plastics, electronics, food, furniture, garments, hotels, information technology, leather products, machinery and equipment, minerals, motor vehicles, non-metallic products, and retail. Details about the sample are reported in Table 1.

TABLE 1

COUNTRIES REPRESENTED IN THE STUDY

\begin{tabular}{lccc}
\hline COUNTRY & UAI & IND & PDI \\
\hline Angola & 60 & 18 & 83 \\
Argentina & 86 & 46 & 49 \\
Bhutan & 28 & 52 & 94 \\
Brazil & 76 & 38 & 69 \\
Burkina Faso & 55 & 15 & 70 \\
Cape Verde & 40 & 20 & 75 \\
Chile & 86 & 23 & 63 \\
Colombia & 80 & 13 & 67 \\
Costa Rica & 86 & 15 & 35 \\
Dominican Republic & 45 & 30 & 65 \\
Ecuador & 67 & 8 & 78 \\
El Salvador & 94 & 19 & 66 \\
Fiji & 48 & 14 & 78 \\
Guatemala & 99 & 6 & 95 \\
Honduras & 50 & 20 & 80 \\
Indonesia & 48 & 14 & 78 \\
Jamaica & 13 & 39 & 45 \\
Malawi & 50 & 30 & 70 \\
Mexico & 82 & 30 & 81 \\
Nepal & 40 & 11 & 65 \\
Panama & 86 & 16 & 95 \\
Peru & 87 & 32 & 64 \\
Philippines & 44 & 16 & 94 \\
Trinidad and Tobago & 55 & 36 & 47 \\
Uruguay & 99 & 12 & 61 \\
Venezuela & 76 & & 70 \\
Vietnam & 30 & & \\
\hline & & & \\
\hline
\end{tabular}

\section{Measures}

The variables measured in this study include borrower access to financing (ACS), SME size, SME funding source, individualism (IND), uncertainty avoidance index (UAI), and power distance index (PDI). ACS was measured as the average of three question items such as "At this time, does this establishment have a line of credit or loan from a financial institution" and "Referring only to the most recent credit or loan, did the financing require collateral?" The funding source was measured with the question item: "Referring to the line of credit or loan, what type of financial institution granted this loan?" SME size was measured based by the firm size reported by the firms in the survey (small $=5-19$ employees; medium = 20-99 employees; large $=$ more than 100 employees). Measures for the moderating variables (individualism 
(IND), uncertainty avoidance index (UAI), and power distance index (PDI)) were the scores reported on the Hofstede country dimensions website (www.Hofstede-Insights.com) for the countries represented in our sample.

\section{Results}

Test of Hypotheses

We tested five hypotheses in this study. In Hypothesis 1, we tested the relationship between SME size and access to financing (ACS). In Hypothesis 2, we tested the relationship between SME funding source (private banks versus state banks) and access to financing (ACS). In Hypothesis 3, 4, and 5, we examined the moderating effects of individualism, uncertainty avoidance, and power distance, respectively, on the relationships between SME size and access to financing and SME funding source and access to financing.

To test Hypothesis 1, we used the SPSS statistical software to perform regression analysis with SME size as the independent variable and access to financing (ACS) as the dependent variable. As reported in Table 2, the overall regression model was significant $(\mathrm{F}=71.724 ; \mathrm{p}=0.000)$. Also, as shown in Table 2, SME size was significant in predicting ACS $(\beta=0.178, \mathrm{p}<0.1)$. Thus, we find support for Hypothesis 1.

TABLE 2

\section{SME SIZE PREDICTING ACCESS TO CREDIT}

\begin{tabular}{rrrr} 
R & R Square & $\begin{array}{c}\text { (a) Model Summary } \\
\text { Adjusted R } \\
\text { Square }\end{array}$ & $\begin{array}{l}\text { Std. Error of } \\
\text { the Estimate }\end{array}$ \\
\hline .178 & 0.032 & 0.031 & 0.719 \\
\hline
\end{tabular}

a. Dependent Variable: ACS

b. Predictors: (Constant): SIZE

\begin{tabular}{lrrrrr} 
& \multicolumn{2}{c}{ (b) ANOVA } & & & Sig \\
& $\begin{array}{c}\text { Sum of } \\
\text { Squares }\end{array}$ & df & Mean Square & F & Sig \\
\hline Regression & 37 & 1 & 37.117 & 71.724 & $.000 \mathrm{~b}$ \\
Residual & 1,129 & 2,182 & 0.517 & & \\
Total & 1,166 & 2,183 & & & \\
\hline
\end{tabular}

a. Dependent Variable: ACS

b. Predictors: (Constant): SIZE

\begin{tabular}{|c|c|c|c|c|c|}
\hline & & Model Sur & $\mathrm{ry}^{\mathrm{a}}$ & \multirow{3}{*}{$\mathrm{t}$} & \multirow{3}{*}{ Sig } \\
\hline & \multicolumn{2}{|c|}{$\begin{array}{l}\text { Unstandardized } \\
\text { Coefficients }\end{array}$} & \multirow{2}{*}{$\begin{array}{l}\text { Standardized } \\
\text { Coefficients } \\
\text { Beta }\end{array}$} & & \\
\hline & $\mathrm{B}$ & Std. Error & & & \\
\hline (Constant) & 1.442 & 0.054 & & 26.643 & 0.000 \\
\hline SIZE & 0.184 & 0.022 & 0.178 & 8.469 & 0.000 \\
\hline
\end{tabular}

a. Dependent Variable: ACS

To test Hypothesis 2, we repeated the procedure for testing Hypothesis 1, running a regression analysis with SME funding source as the independent variable and access to financing (ACS) as the dependent variable. As reported in Table 3, the overall regression model was significant $(F=134.557 ; p=0.000)$. Also, as shown in Table 3, SME funding source was significant in predicting ACS $(\beta=-0.241, \mathrm{p}<0.1)$. The negative coefficient is due to the reverse coding effect of the question item that we used to measure SME funding source. Thus, we find support for Hypothesis 2. 
TABLE 3

SME FUNDING SOURCE PREDICTING ACCESS TO CREDIT

\begin{tabular}{rrrr} 
R & R Square & (a) Model Summary \\
Adjusted R & $\begin{array}{l}\text { Std. Error of } \\
\text { the Estimate }\end{array}$ \\
\hline $.241 \mathrm{a}$ & 0.058 & 0.058 & 0.710 \\
\hline
\end{tabular}

a. Dependent Variable: ACS

b. Predictors: (Constant): SOURCE

\begin{tabular}{lrrrrr} 
& \multicolumn{2}{c}{ (b) ANOVA } & & & Sig \\
& $\begin{array}{c}\text { Sum of } \\
\text { Squares }\end{array}$ & df & Mean Square & F & Sig \\
\hline Regression & 68 & 1 & 67.744 & 134.557 & $.000 \mathrm{~b}$ \\
Residual & 1,099 & 2,182 & 0.503 & & \\
Total & 1,166 & 2,183 & & & \\
\hline
\end{tabular}

a. Dependent Variable: ACS

b. Predictors: (Constant): SOURCE

\begin{tabular}{|c|c|c|c|c|c|}
\hline & \multicolumn{3}{|c|}{ (c) Model Summarya } & \multirow{3}{*}{$\mathrm{t}$} & \multirow{3}{*}{ Sig } \\
\hline & \multicolumn{2}{|c|}{$\begin{array}{c}\text { Unstandardized } \\
\text { Coefficients }\end{array}$} & \multirow{2}{*}{$\begin{array}{l}\text { Standardized } \\
\text { Coefficients } \\
\text { Beta }\end{array}$} & & \\
\hline & $\mathrm{B}$ & Std. Error & & & \\
\hline (Constant) & 2.343 & 0.043 & & 54.980 & 0.000 \\
\hline SIZE & -0.371 & 0.032 & -0.241 & -11.600 & 0.000 \\
\hline
\end{tabular}

a. Dependent Variable: ACS

We tested Hypothesis 3(a) by performing a forced-entry moderating regression analysis of SME size, access to financing (ACS), and individualism (IND), using the 'PROCESS' add-in of SPSS. To control for high and low individualism, we used the median split method to categorize individualism into high and low categories (Knüppel and Hermsen 2010, Sedney 1981). Next, we regressed the combined high and low individualism (IND) scores against SME size and ACS. We repeated the process for the low and high individualism scores in separate regression analyses. Table 4 displays the results of Hypotheses 3(a). As reported in Table 4, the $\beta$ and t-statistics of the interaction term for the combined, low, and high IND scores are $0.002(\mathrm{p}>0.10), 0.017(\mathrm{p}>0.10)$, and $0.000(\mathrm{p}>0.10)$, respectively. Thus, we find no support for Hypothesis 3(a).

TABLE 4

IMPACTS OF INDIVIDUALISM ON SME SIZE AND ACCESS TO FINANCING

\begin{tabular}{lccc} 
& \multicolumn{3}{c}{$\begin{array}{c}\text { Consequent } \\
\text { Access to Credit }\end{array}$} \\
\cline { 2 - 4 } $\begin{array}{c}\text { Antecedent } \\
\text { Interaction of Predictor and Moderator }\end{array}$ & Coefficient & $\mathrm{p}$ & $\mathrm{R}^{2}$ \\
\hline SIZE X IND (High and Low) & 0.002 & 0.354 & 0.086 \\
SIZE X IND (Low) & 0.017 & 0.207 & 0.038 \\
SIZE X IND (High) & -0.000 & 0.311 & 0.214 \\
\hline
\end{tabular}

We tested Hypothesis 3(b) by repeating the procedures to test Hypothesis 3(a) with SME funding source, access to credit (ACS), and individualism (IND). Table 5 displays the results of Hypothesis 3(b). 
As reported in Table 5, the $\beta$ and t-statistics of the interaction terms for the combined, low, and high IND scores are $0.007(\mathrm{p}<0.10), 0.002(\mathrm{p}>0.10)$, and $0.000(\mathrm{p}>0.10)$, respectively. Thus, we find partial support for $\mathrm{H} 3(\mathrm{~b})$.

TABLE 5

IMPACTS OF INDIVIDUALISM ON SME FUNDING SOURCE AND ACCESS TO FINANCING

\begin{tabular}{lccc}
\multicolumn{1}{c}{$\begin{array}{c}\text { Antecedent } \\
\text { Anted }\end{array}$} & \multicolumn{3}{c}{$\begin{array}{c}\text { Consequent } \\
\text { Access to Credit }\end{array}$} \\
\cline { 2 - 4 } Interaction of Predictor and Moderator & Coefficient & $\mathrm{p}$ & $\mathrm{R}^{2}$ \\
\hline SOURCE X IND (High and Low) & 0.007 & 0.015 & 0.117 \\
SOURCE X IND (Low) & 0.002 & 0.925 & 0.043 \\
SOURCE X IND (High) & 0.000 & 0.893 & 0.225 \\
\hline
\end{tabular}

We tested Hypothesis 4(a) by repeating the procedures in Hypothesis 3(a) with SME size, ACS, and uncertainty avoidance index (UAI). Table 6 displays the results of Hypotheses 4(a). As reported in Table 6 , the $\beta$ and t-statistics of the interaction terms for the combined, low, and high UAI scores are 0.027 (p > $0.10), 0.000(p>0.10)$, and $0.000(p>0.10)$ respectively. Thus, we find no support for H4(a).

TABLE 6

IMPACTS OF UNCERTAINTY AVOIDANCE ON SME SIZE AND ACCESS TO FINANCING

Consequent

Access to Credit

\begin{tabular}{lccc}
\cline { 2 - 4 } \multicolumn{1}{c}{ Antecedent } & & $\mathrm{p}$ & $\mathrm{R}^{2}$ \\
Interaction of Predictor and Moderator & Coefficient & 0.855 & 0.288 \\
\hline SIZE X IND (High and Low) & 0.002 & 0.910 & 0.181 \\
SIZE X IND (Low) & 0.000 & 0.311 & 0.214 \\
SIZE X IND (High) & -0.000 & \\
\hline
\end{tabular}

We tested for Hypothesis 4(b) by repeating the procedures in Hypothesis 3(b) with SME funding source, ACS, and UAI. Table 7 displays the results of Hypotheses 4(b). As reported in Table 7, the $\beta$ and $\mathrm{t}$-statistics of the interaction terms for the combined, low, and high UAI scores are 0.337 ( $p>0.10), 0.000$ ( $\mathrm{p}>0.10)$, and $-0.014(\mathrm{p}<0.10)$ respectively. Thus, we find partial support for H4(b).

TABLE 7

IMPACTS OF UNCERTAINTY AVOIDANCE ON SME FUNDING SOURCE AND ACCESS TO FINANCING

\begin{tabular}{lccc}
\multicolumn{1}{c}{$\begin{array}{c}c \\
\text { Antecedent }\end{array}$} & \multicolumn{3}{c}{$\begin{array}{c}\text { Consequent } \\
\text { Access to Credit }\end{array}$} \\
\cline { 2 - 4 } Interaction of Predictor and Moderator & Coefficient & $\mathrm{p}$ & $\mathrm{R}^{2}$ \\
\hline SOURCE X IND (High and Low) & 0.001 & 0.337 & 0.287 \\
SOURCE X IND (Low) & -0.000 & 0.925 & 0.043 \\
SOURCE X IND (High) & -0.014 & 0.046 & 0.011 \\
\hline
\end{tabular}

We tested for Hypothesis 5(a) by repeating the procedures in Hypothesis 4(a) with SME size, ACS, and PDI. Table 8 displays the results of Hypothesis 5(a). As reported in Table 8, the $\beta$ and t-statistics of the 
interaction terms for the combined, low, and high PDI scores are $-0.006(\mathrm{p}<0.10), 0.002(\mathrm{p}>0.10)$, and 0.003 ( $\mathrm{p}>0.10$ ) respectively. Thus, we find partial support for H5(a).

TABLE 8

IMPACTS OF POWER DISTANCE ON SME SIZE AND ACCESS TO FINANCING

\begin{tabular}{lccc} 
& \multicolumn{3}{c}{$\begin{array}{c}\text { Consequent } \\
\text { Access to Credit }\end{array}$} \\
\cline { 2 - 4 } \multicolumn{1}{c}{ Antecedent } & & & $\mathrm{R}^{2}$ \\
Interaction of Predictor and Moderator & Coefficient & $\mathrm{p}$ & 0.075 \\
\hline SIZE X IND (High and Low) & -0.006 & 0.003 & 0.112 \\
SIZE X IND (Low) & 0.002 & 0.643 & 0.012 \\
SIZE X IND (High) & 0.003 & 0.355 & \\
\hline
\end{tabular}

We tested for Hypothesis 5(b) by performing repeating the procedures in Hypothesis 4(a) with funding source, ACS, and PDI. Table 9 displays the results of Hypotheses $5(\mathrm{~b})$. As reported in Table 9 , the $\beta$ and $t-$ statistics of the interaction terms for the combined, low, and high PDI scores are $0.011(\mathrm{p}<0.10), 0.012$ ( $\mathrm{p}$ $<0.10)$, and $0.006(\mathrm{p}=0.10)$ respectively. Thus, we find support for $\mathrm{H} 5(\mathrm{~b})$.

TABLE 9

IMPACTS OF POWER DISTANCE ON SME FUNDING SOURCE AND ACCESS TO FINANCING

\begin{tabular}{lccc} 
& \multicolumn{3}{c}{$\begin{array}{c}\text { Consequent } \\
\text { Access to Credit }\end{array}$} \\
\cline { 2 - 4 } $\begin{array}{c}\text { Antecedent } \\
\text { Interaction of Predictor and Moderator }\end{array}$ & Coefficient & $\mathrm{p}$ & $\mathrm{R}^{2}$ \\
\hline SOURCE X IND (High and Low) & 0.011 & 0.000 & 0.106 \\
SOURCE X IND (Low) & 0.012 & 0.040 & 0.058 \\
SOURCE X IND (High) & 0.006 & 0.100 & 0.011 \\
\hline
\end{tabular}

To confirm the results in Hypothesis 3(b), 4(b), and 5(b), we created moderating slopes to further analyze the impacts of IND, UAI, and PDI on the relationship between SME funding source and access to financing. The moderation slopes in Figure 2 illustrate the conditional effects of individualism on access to credit at various levels of collectivism at the $95 \%$ confidence interval level. As shown in Figure 2, at the highest point of individualism (26.9075), the effect of individualism on access to financing is at the highest point (-0.1734). Conversely, at the lowest point of individualism (-19.0925), the effect of individualism on access to financing is at the lowest point $(-0.4931)$. Thus, as individualism increases, its effect on access to financing increases, supporting our conclusion for Hypothesis 3(b). 
FIGURE 2

THE MODERATING EFFECTS OF INDIVIDUALISM ON THE RELATIONSHIP BETWEEN SME FUNDING SOURCE AND ACCESS TO FINANCING

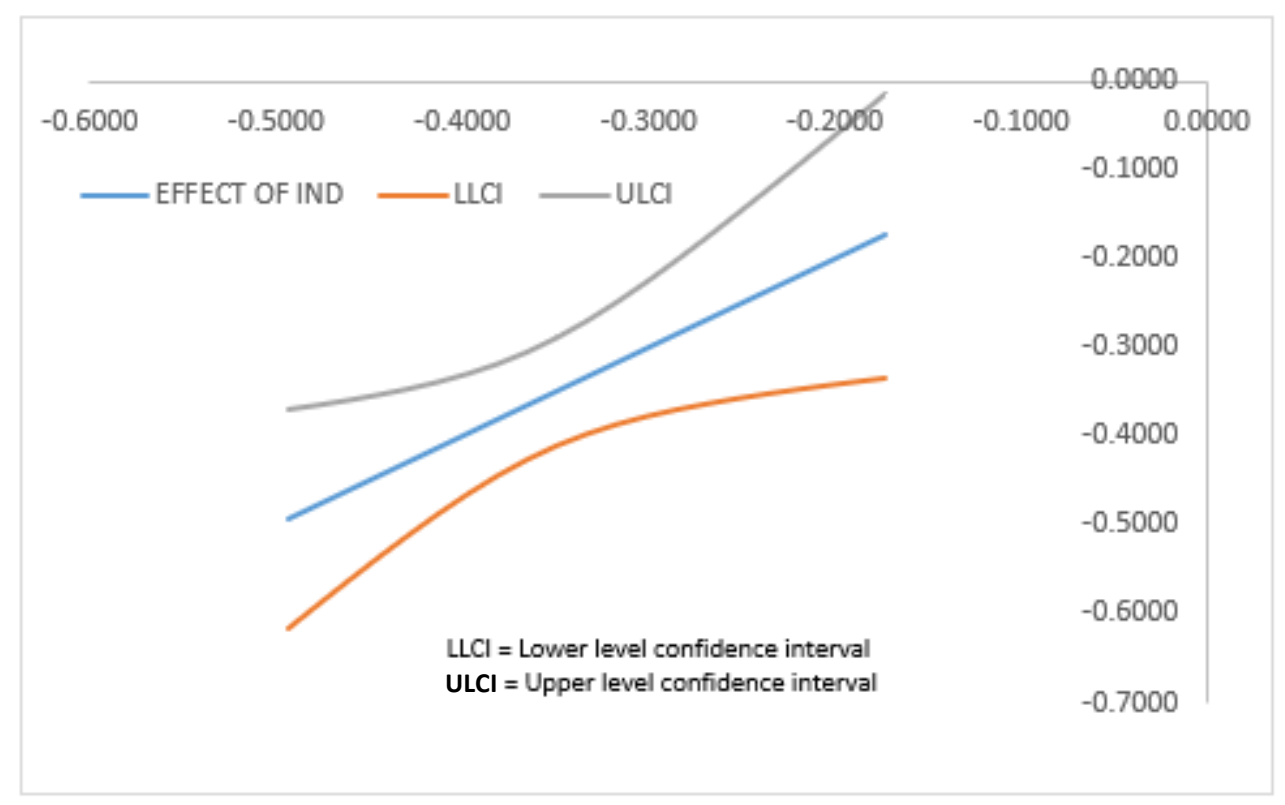

As shown in Figure 3, at the highest point of uncertainty avoidance (15.3026), the effect of uncertainty avoidance on access to financing is at the lowest point (-0.6669). Conversely, at the lowest point of uncertainty avoidance (-23.6974), the effect of uncertainty avoidance on access to financing is at the highest point (-0.1609). Thus, as uncertainty avoidance increases, its effect on access to financing decreases, supporting our conclusion for Hypothesis 4(b).

FIGURE 3

THE MODERATING EFFECTS OF UNCERTAINTY AVOIDANCE ON THE RELATIONSHIP BETWEEN SME FUNDING SOURCE AND ACCESS TO FINANCING

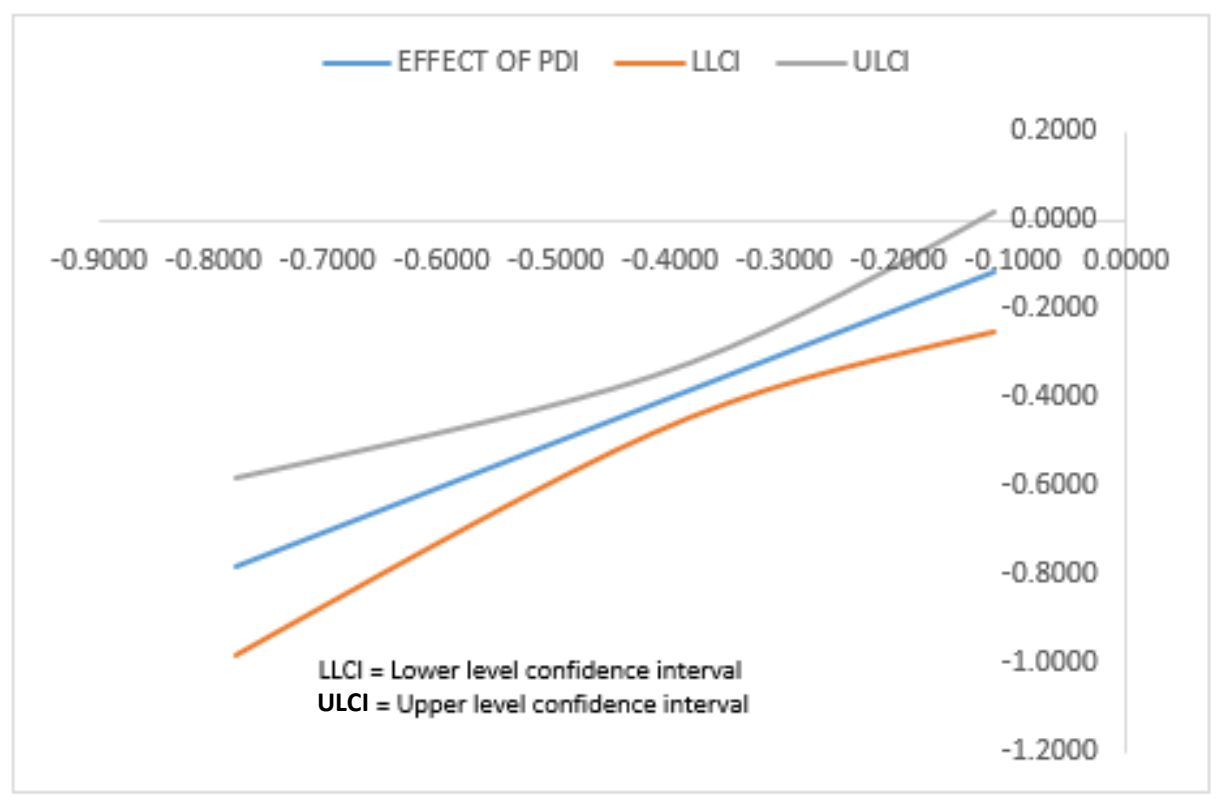


As shown in Figure 4, at the highest point of power distance (24.2386), the effect of power distance on access to financing is at the highest point (-0.2506). Conversely, at the lowest point of power distance (35.7614), the effect of power distance on access to financing is at the lowest point (-0.9809). Thus, as power distance increases, its effect on access to financing increases, supporting our conclusion for Hypothesis $5(b)$.

FIGURE 4

THE MODERATING EFFECTS OF POWER DISTANCE ON THE RELATIONSHIP BETWEEN SME FUNDING SOURCE AND ACCESS TO FINANCING

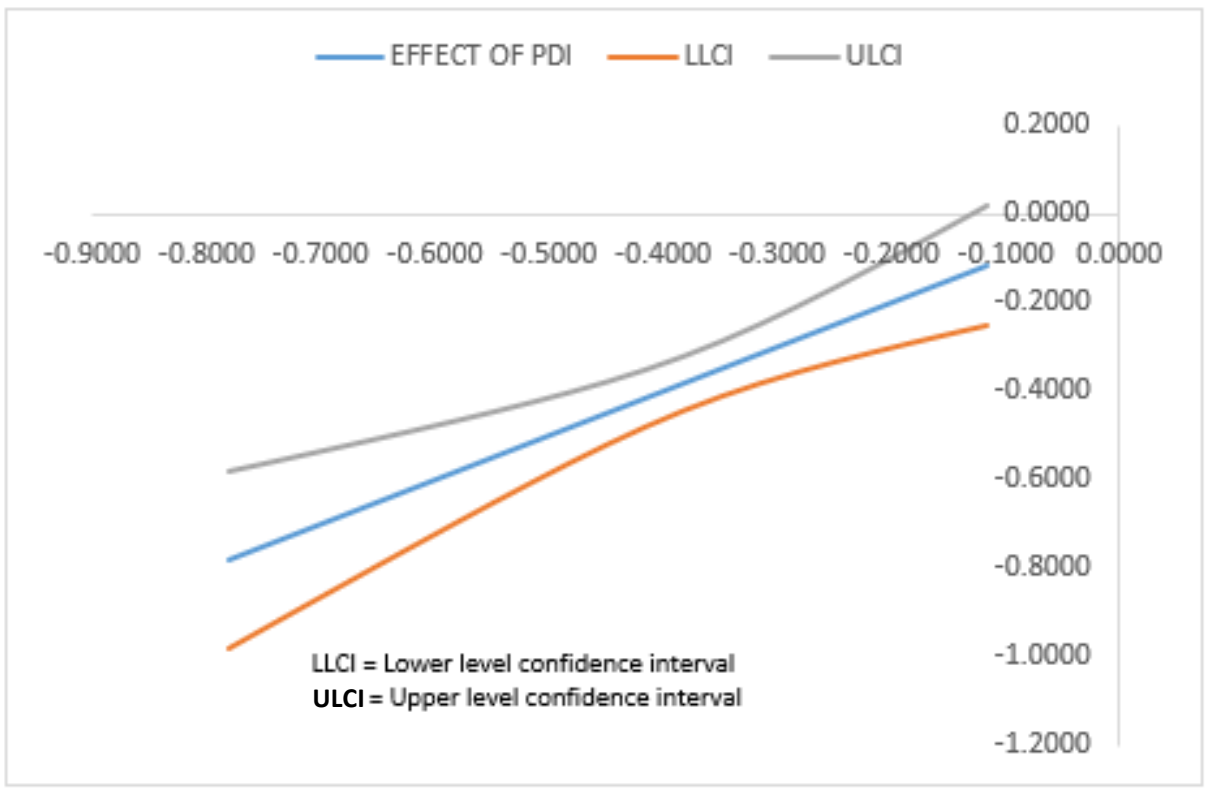

\section{Robustness Tests}

In this study, we controlled for the high and low dimensions of culture using the median split method. However, we acknowledge the possibility of rival hypotheses that could explain SME access to financing. To address this concern, we controlled for SME information disclosure (SID) as an alternative predictive variable of SME access to financing. We settled on SME information disclosure for two reasons. First, due to missing data issues in the sample, we could not identify alternate predicting variables besides SME size, funding source, and information disclosure. Second, information disclosure is an established predictor of access to financing (Asare et al. 2020).

To control for SME information disclosure, we performed four regression analyses. First, we regressed SME size against access to financing. As reported in Table 2, the overall regression model was significant $(\mathrm{F}=71.724 ; \mathrm{p}=0.000)$. Also, as shown in Table $2, \mathrm{SME}$ size was significant in predicting ACS $(\beta=0.178$, $\mathrm{p}<0.10)$.

Second, we regressed information disclosure against SME size. As reported in Table 10, the overall regression model was significant $(\mathrm{F}=262.331 ; \mathrm{p}=0.000)$. Also, as shown in Table 10, SME information disclosure is significant in predicting SME size $(\beta=0.328, \mathrm{p}<0.10)$. 


\section{TABLE 10}

SME INFORMATION DISCLOSURE PREDICTING SME SIZE

\begin{tabular}{rrrr} 
R & R Square & $\begin{array}{c}\text { (a) Model Summary } \\
\text { Adjusted R } \\
\text { Square }\end{array}$ & $\begin{array}{l}\text { Std. Error of } \\
\text { the Estimate }\end{array}$ \\
\hline $.328 \mathrm{a}$ & 0.107 & 0.107 & 0.670 \\
\hline
\end{tabular}

a. Dependent Variable: SIZE

b. Predictors: (Constant): SID

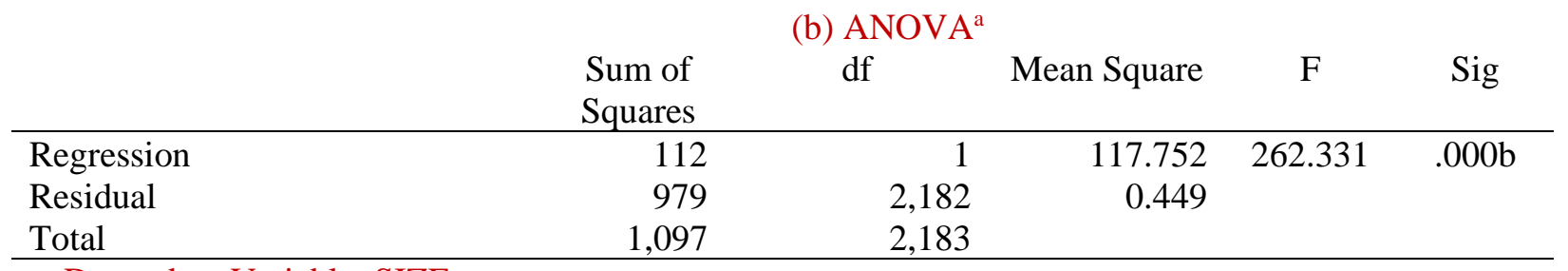

a. Dependent Variable: SIZE

b. Predictors: (Constant): SID

\begin{tabular}{|c|c|c|c|c|c|}
\hline & \multicolumn{3}{|c|}{ (c) Model Summarya } & \multirow{3}{*}{$\mathrm{t}$} & \multirow{3}{*}{ Sig } \\
\hline & \multicolumn{2}{|c|}{$\begin{array}{l}\text { Unstandardized } \\
\text { Coefficients }\end{array}$} & \multirow{2}{*}{$\begin{array}{c}\text { Standardized } \\
\text { Coefficients } \\
\text { Beta }\end{array}$} & & \\
\hline & $\mathrm{B}$ & Std. Error & & & \\
\hline (Constant) & 1.066 & 0.083 & & 12.856 & 0.000 \\
\hline SIZE & 0.495 & 0.031 & 0.328 & 16.197 & 0.000 \\
\hline
\end{tabular}

a. Dependent Variable: SIZE

Third, we regressed SME information disclosure against SME access to financing. As reported in Table 11 , the overall regression model was significant $(\mathrm{F}=103.513 ; \mathrm{p}=0.000)$. Also, as shown in Table 11, SME information disclosure was significant in predicting $\operatorname{ACS}(\beta=0.213, \mathrm{p}<0.10)$.

TABLE 11

SME INFORMATION DISCLOSURE PREDICTING SME ACCESS TO FINANCING

\begin{tabular}{rrrr} 
R & R Square & $\begin{array}{c}\text { (a) Model Summary } \\
\text { Adjusted R } \\
\text { Square }\end{array}$ & $\begin{array}{l}\text { Std. Error of } \\
\text { the Estimate }\end{array}$ \\
\hline $.213 \mathrm{a}$ & 0.045 & 0.045 & 0.714 \\
\hline
\end{tabular}

a. Dependent Variable: ACS

b. Predictors: (Constant): SID

\begin{tabular}{|c|c|c|c|c|c|}
\hline & \multicolumn{3}{|c|}{ (b) $\mathrm{ANOVA}^{\mathrm{a}}$} & \multirow[b]{2}{*}{$\mathrm{F}$} & \multirow[b]{2}{*}{ Sig } \\
\hline & $\begin{array}{l}\text { Sum of } \\
\text { Squares }\end{array}$ & & Mean Square & & \\
\hline Regression & 53 & 1 & 52,822 & 103,513 & $.000 \mathrm{~b}$ \\
\hline Residual & 1,113 & 2,182 & 0.510 & & \\
\hline Total & 1,166 & 2,183 & & & \\
\hline
\end{tabular}

a. Dependent Variable: SIZE

b. Predictors: (Constant): SID 
(c) Model Summary

\begin{tabular}{lcc|c|c|c} 
& \multicolumn{2}{c|}{$\begin{array}{c}\text { Unstandardized } \\
\text { Coefficients }\end{array}$} & $\begin{array}{l}\text { Standardized } \\
\text { Coefficients }\end{array}$ & t & \multirow{2}{*}{ Sig } \\
\cline { 1 - 3 } & $\mathrm{B}$ & Std. Error & Beta & & \\
\hline (Constant) & 1.995 & 0.088 & & 11.253 & 0.000 \\
SIZE & 0.335 & $3,033.000$ & 0.213 & 10.174 & 0.000 \\
\hline
\end{tabular}

a. Dependent Variable: ACS

Finally, we regressed firm size and financial information disclosure against access to financing. As reported in Table 12, the overall regression model was significant $(F=68.794 ; p=0.000)$. Also, as shown in Table 12, both SME firm size and information disclosure were significant in predicting access to financing $(\beta=0.120, p<0.10$ and $\beta=0.175, p<0.10$, respectively).

TABLE 12

SME INFORMATION DISCLOSURE AND SIZE PREDICTING ACCESS TO FINANCING

\begin{tabular}{rrrr} 
R & R Square & $\begin{array}{c}\text { (a) Model Summary } \\
\text { Adjusted R } \\
\text { Square }\end{array}$ & $\begin{array}{l}\text { Std. Error of } \\
\text { the Estimate }\end{array}$ \\
\hline $.243 \mathrm{a}$ & 0.059 & 0.058 & 0.709 \\
\hline
\end{tabular}

a. Dependent Variable: ACS

b. Predictors: (Constant): SIZE, SID

\begin{tabular}{lrrrrr} 
& \multicolumn{2}{c}{ (b) ANOVA } & \multicolumn{2}{c}{ Sum of } \\
Squares & df & Mean Square & F & Sig \\
\hline Regression & 69 & 2 & 34.598 & 68.794 & $.000 \mathrm{~b}$ \\
Residual & 1,101 & 2,182 & 0.503 & & \\
Total & 1,170 & 2,183 & & & \\
\hline
\end{tabular}

a. Dependent Variable: ACS

b. Predictors: (Constant): SIZE, SID

\begin{tabular}{lcc|c|c|c} 
& \multicolumn{2}{c}{$\begin{array}{c}\text { Unstandardized } \\
\text { Coefficients }\end{array}$} & $\begin{array}{l}\text { Standardized } \\
\text { Coefficients }\end{array}$ & \multirow{2}{*}{$\mathrm{t}$} & \multirow{2}{*}{ Sig } \\
\cline { 1 - 2 } & $\mathrm{B}$ & Std. Error & Beta & & \\
\hline (Constant) & 0.858 & 0.091 & & 9.453 & 0.000 \\
SIZE & 0.124 & 0.023 & 0.120 & 5.457 & 0.000 \\
SID & 0.273 & 0.034 & 0.175 & 7.983 & 0.000 \\
\hline
\end{tabular}

a. Dependent Variable: ACS

We also performed the robustness test for the relationship between SME funding source and access to financing. First, we regressed SME funding source against access to financing. As reported in Table 3, the overall regression model is significant with an $\mathrm{R}^{2}$ of 0.032 . Also, as shown in Table 3 , SME funding source is significant in predicting ACS $(\beta=0.178, \mathrm{p}<0.1)$.

Second, we regressed information disclosure against SME funding source. As reported in Table 13, the overall regression model was significant $(\mathrm{F}=64.030 ; \mathrm{p}=0.000)$. Also, as shown in Table 13, SME information disclosure is significant in predicting SME funding source $(\beta=-0.169, \mathrm{p}<0.10)$. 
TABLE 13

SME INFORMATION DISCLOSURE PREDICTING SME FUNDING SOURCE

\begin{tabular}{rrrr}
$\mathrm{R}$ & R Square & $\begin{array}{c}\text { (a) Model Summary } \\
\text { Adjusted R } \\
\text { Square }\end{array}$ & $\begin{array}{l}\text { Std. Error of } \\
\text { the Estimate }\end{array}$ \\
\hline .169 & 0.029 & 0.028 & 0.468 \\
\hline
\end{tabular}

a. Dependent Variable: SOURCE

b. Predictors: (Constant): SID

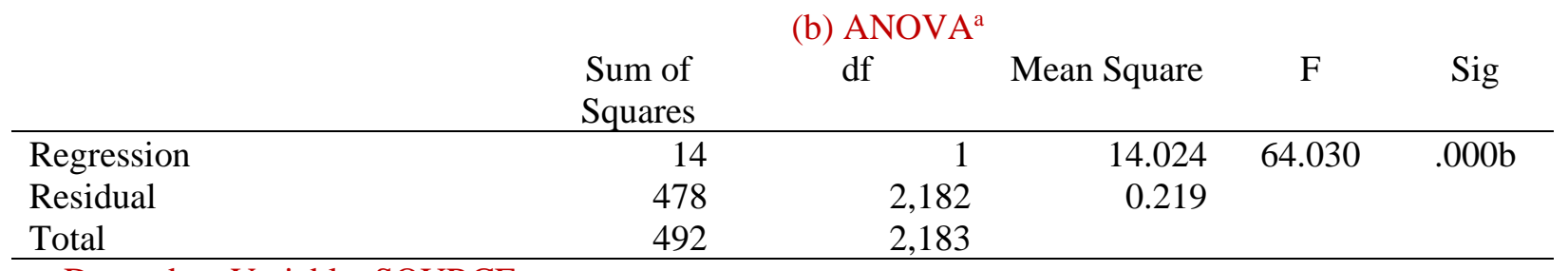

a. Dependent Variable: SOURCE

b. Predictors: (Constant): SID

\begin{tabular}{|c|c|c|c|c|c|}
\hline & \multicolumn{3}{|c|}{ (c) Model Summary } & \multirow{3}{*}{$\mathrm{t}$} & \multirow{3}{*}{ Sig } \\
\hline & \multicolumn{2}{|c|}{$\begin{array}{l}\text { Unstandardized } \\
\text { Coefficients }\end{array}$} & \multirow{2}{*}{$\begin{array}{l}\text { Standardized } \\
\text { Coefficients } \\
\text { Beta }\end{array}$} & & \\
\hline & B & Std. Error & & & \\
\hline (Constant) & 1.702 & 0.058 & & 23.369 & 0.000 \\
\hline SIZE & -0.171 & 0.021 & -0.169 & -8.002 & 0.000 \\
\hline
\end{tabular}

a. Dependent Variable: SOURCE

Third, we regressed SME information disclosure against SME access to financing. As reported in Table 11 , the overall regression model was significant $(\mathrm{F}=52.822 ; \mathrm{p}=0.000)$. Also, as shown in Table 11, SME funding source is significant in predicting $\operatorname{ACS}(\beta=0.215, \mathrm{p}<0.10)$.

Finally, we regressed SME funding source and financial information disclosure against access to financing. As reported in Table 14, the overall regression model was significant $(F=105.986 ; p=0.000)$. Also, as shown in Table 14, both SME funding source and information disclosure were significant in predicting access to financing $(\beta=0.177, \mathrm{p}<0.10$ and $\beta=-0.211, \mathrm{p}<0.10$, respectively).

\section{TABLE 14 \\ SME INFORMATION DISCLOSURE AND FUNDING SOURCE PREDICTING ACCESS TO FINANCING}

\begin{tabular}{rrrr} 
R & R Square & $\begin{array}{c}\text { (a) Model Summary } \\
\text { Adjusted R } \\
\text { Square }\end{array}$ & $\begin{array}{l}\text { Std. Error of } \\
\text { the Estimate }\end{array}$ \\
\hline $.298 \mathrm{a}$ & 0.089 & 0.088 & 0.698 \\
\hline
\end{tabular}

a. Dependent Variable: ACS

b. Predictors: (Constant): SOURCE, SID 
(b) ANOVA $^{\text {a }}$

\begin{tabular}{lrrrrr} 
& $\begin{array}{c}\text { Sum of } \\
\text { Squares }\end{array}$ & df & Mean Square & F & Sig \\
\hline Regression & 103 & 2 & 51.655 & 105.986 & $.000 \mathrm{~b}$ \\
Residual & 1,063 & 2,181 & 0.478 & & \\
Total & 1,166 & 2,183 & & & \\
\hline
\end{tabular}

a. Dependent Variable: ACS

b. Predictors: (Constant): SOURCE, SID

\begin{tabular}{|c|c|c|c|c|c|}
\hline & \multicolumn{3}{|c|}{ (c) Model Summary ${ }^{\mathrm{a}}$} & \multirow{3}{*}{$\mathrm{t}$} & \multirow{3}{*}{ Sig } \\
\hline & \multicolumn{2}{|c|}{$\begin{array}{l}\text { Unstandardized } \\
\text { Coefficients }\end{array}$} & \multirow{2}{*}{$\begin{array}{l}\text { Standardized } \\
\text { Coefficients }\end{array}$} & & \\
\hline & B & Std. Error & & & \\
\hline (Constant) & 1.548 & 0.102 & & 15.166 & 0.000 \\
\hline SIZE & 0.276 & 0.032 & 0.177 & 8.543 & 0.000 \\
\hline SID & -0.325 & 0.032 & -0.211 & -10.178 & 0.000 \\
\hline
\end{tabular}

a. Dependent Variable: ACS

The results of the robustness tests confirm the findings from extant literature; SME information disclosure promotes SME access to credit. However, both SME size and funding sources are still effective in predicting access to financing in the multiple regression models. Thus, we found that SME size and funding sources are predictors of access to financing after controlling for information disclosure.

\section{DISCUSSION}

This study adds to the accounting and finance literature by examining SMEs in developing economies in four areas. These areas are the moderating influence of culture, alternative SME financing sources, determinants of SME access to financing, and the internationalization of SMEs. These four perspectives have implications for both theory and practice.

\section{Implications for Theory}

The primary objective of this paper was to examine the moderating effects of culture on two determinants of SME financing in developing economies: SME size and funding source. We hypothesized and found that SME size and funding sources do determine accessibility to financing in developing economies. According to our results, larger SMEs have more access to financing than smaller SMEs. These results are consistent with prior research (Asare et al. 2020). We also found that private banks are more likely to provide financing to SMEs than state-owned banks. These results are also consistent with prior research (Sapienza 2004).

From the social view, our results show that state-owned banks in developing economies have not lived up to expectations in terms of SME financing. Future research should investigate whether the cost of stateowned banks outweighs the benefits in these economies (e.g. providing accessible financing to SMEs). In particular, what is the economic cost to establish and maintain state-owned banks? Is it worth keeping these banks, if they are not lending to SMEs? Future research should also look into governance mechanisms that assist SMEs in accessing financing from state-owned banks, especially in developing and emerging economies. For example, what lessons could be learned from advanced economies such as the United States that have strong government-backed financing schemes executed through partnerships with the private sector?

Our results also reveal that some cultural dimensions (individualism, uncertainty avoidance, and power distance) influence the relationship between SME funding source and access to financing. In other words, culture is critical to SME's access to financing from private banks in developing economies as our results 
indicated. Future research should investigate the role of culture in SME's access to financing from stateowned banks.

Due to data availability issues, this paper focused only on the individualism, uncertainty avoidance, and power distance cultural dimensions. Future research should examine the impact of other Hofstede country dimensions (i.e., masculinity, long term orientation, and indulgence) on SME financing in developing economies, which have received little attention in the literature.

Culture has been represented exclusively in this paper with Hofstede's country dimensions as proxies. However, there are other cultural factors such as language, tribe, ethnicity, customs, and traditions that are not captured in Hofstede's country dimensions. Studies show those cultural factors influence societal values such as social networks, which in turn influence access to jobs, political affiliations, and some social amenities. With this background, future research could investigate how those cultural factors influence SME access to credit and financing in developing economies.

We did not find support for the moderating influence of individualism and uncertainty avoidance on the relationship between SME size and access to financing. However, prior accounting researchers (Asare et al. 2010, Kanagaretnam et al. 2014) found these cultural values to influence both bank lending behavior and borrower information disclosure practices, which was influenced by firm size. Future research should examine why this is the case. For instance, do SMEs grow out of cultural biases and influences as they expand or become part of large international organizations? Is SME financing source, public or private, immune to cultural biases? If so, what lessons could be applied to other dependents of SME access to credit and financing?

Consistent with the prior literature, the results of this study show that culture plays a significant role in SME financing in developing economies. We acknowledge that our sample was limited to only 27 developing economies. Future studies should look at expanding the number of economies and to test the role of culture on SME financing. Also, given culture's impact, SMEs are likely to face challenges as they seek international financing when expanding beyond their home country. Thus, future research should look at potential financing obstacles that SMEs are likely to face in their internationalization efforts.

\section{Implications for Practice}

Our findings seem to suggest that state-owned or public banks in developing nations provide more access to capital to large firms, leaving SMEs with little to no choice but to source from the private sector banks, often at higher rates. Since SMEs form the backbone of most developing economies, it is imperative that governments ensure greater transparency when it comes to lending through public banks as transparency is still a problem in developing economies (Belal et al. 2013). While the International Financial Reporting Standard (IFRS) has improved transparency to some extent (Gassen 2017) more work is needed. Moreover, we recommend that public banks make concerted efforts to encourage the growth of SMEs by having targeted lending programs.

In addition, SMEs face significant hurdles when borrowing internationally due to culture. To help level the playing field and overcome cultural barriers, home countries should create agencies to not only help in information flow, but also to help in enabling SMEs in their journey to secure audited financial statements. Local government agencies could also facilitate in the process of securing international loans by authenticating and validating the SMEs - almost akin to securing a letter of credit in international trade.

\section{CONCLUSION}

Small and medium-sized enterprises (SMEs) are critical for the growth of developing economies. Extant literature has shown that access to financing is very important for SMEs in developing economies for sustained growth and development. Yet, as our research shows, several factors affect SMEs ability to secure financing, which is further amplified by cultural factors. As outlined in our discussion, academics need to renew their focus on SME financing. Public and private financial sectors in developing economies need to renew and improve their efforts to enable better access to financing for SMEs, and work to eradicate discriminatory lending in these countries (Saliya and Jayasinghe 2016). Last year, the announcement of the 
European Investment Bank (EIB) and Spanish bank Banco Bilbao Vizcaya Argentaria (BBVA) to make 600 million euros available for SMEs in Spain is a step in the right direction. Perhaps, this type of publicprivate partnership will pave the way for other partnerships in the future that will benefit SMEs in developing economies.

\section{REFERENCES}

Afrifa, G.A., \& Tingbani, I. (2018). Working capital management, cash flow and SMEs' performance. Int. J. Banking, Accounting and Finance, 9(1), 19-43.

Agrawal, A.K., Catalini, C., \& Goldfarb, A. (2011). The geography of crowdfunding. NBER Working Paper.

Amidu, M., Effah, J., \& Abor, J. (2011). E-Accounting practices among small and medium enterprises in Ghana. Journal of Management Policy \& Practice, 12(4), 146-155.

Angeles, A., Centeno, E., \& Villanueva, C.E. (2019). Examining structural flexibility factors in SMEs: A mixed-methods study in Mexico. The Electronic Journal of Business Research Methods, 17(1), $28-42$.

Angori, G., Aristei, D., \& Gallo, M. (2019). Lending technologies, banking relationships, and firms' access to credit in Italy: The role of firm size. Applied Economics, 51(58), 6139-6170.

Armstrong, C.S., Core, J.E., Taylor, D.J., \& Verrecchia, R.E. (2011). When does information asymmetry affect the cost of capital? Journal of Accounting Research, 49(1), 1-40.

Arnold, D.F., Bernardi, R.A., \& Neidermeyer, P.E. (2005). Auditor perspectives on confidentiality: A qualitative investigation examining the differences in European auditors' opinions. The Irish Accounting Review, 12(2), 1-21.

Asare, E.K., Beldona, S., \& Nketia, J. (2020). The principal, the agent, and the culture: Potential impacts of culture on financing contracts. International Trade Journal, 34(1), 30-54.

Atkinson, A.B., \& Stiglitz, J.E. (1980). Lectures on Public Economics. New York, NY.

Audretsch, D.B. (2002). The dynamic role of small firms: Evidence from the U.S. Small Business Economics, 18, 13-40.

Belal, A.R., Cooper, S.M., \& Roberts, R.W. (2013). Vulnerable and exploitable: The need for organisational accountability and transparency in emerging and less developed economies, Accounting Forum, 37(2), 81-91.

Baiman, S., Netessine, S., \& Saouma, R. (2010). Informativeness, incentive compensation, and the choice of inventory buffer. Accounting Review, 85(6), 1839-1860.

Baiman, S., \& Verrecchia, R.E. (1996). The relation among capital markets, financial disclosure, production efficiency, and insider trading. Journal of Accounting Research, 34(1), 1-22.

Banerjee, A.V. (1997). A theory of misgovernance. Quarterly Journal of Economics, 112, 1289-1332.

Barron, O.E., \& Hong, Q. (2014). Information asymmetry and the ex-ante impact of public disclosure quality on price efficiency and the cost of capital: Evidence from a laboratory market. Accounting Review, 89(4), 1269-1297.

Barry, T.A., Lepetit, L., \& Strobel, F. (2017). Bank ownership structure, lending corruption, and the regulatory environment. Journal of Comparative Economics, 44(3), 732-751.

Barth, J.R., Lin, C., Lin, P., \& Song, F.M. (2009). Corruption in bank lending to firms: Cross-country micro evidence on the beneficial role of competition and information sharing. Journal of Financial Economics, 91(3), 361-388.

Beck, T., Demirgüç-Kunt, A., \& Maksimovic, V. (2008). Financing patterns around the world: Are small firms different? Journal of Financial Economics, 89(3), 467-487.

Beck, T., Demirgüç-Kunt, A., \& Maksimovic, A. (2005). Financial and legal constraints to growth: Does firm size matter? The Journal of Finance, 60(10), 137-177.

Beck, T., Demirgüç-Kunt, A., \& Pería, M.S.M. (2011). Bank financing for SMEs: Evidence across countries and bank ownership types. Journal of Financial Services Research, 39(1-2), 35-54. 
Bell, G.R., Filatotchev, I., \& Rasheed, A.A. (2012). The liability of foreignness in capital markets: Sources and remedies. Journal of International Business Studies, 43(2), 107-122.

Belleflamme, P., Lambert, T., \& Schwienbacher, A. (2013). Individual crowdfunding practices. Venture Capital, 15, 313-333.

Belleflamme, P., Lambert, T., \& Schwienbacher, A. (2014). Crowdfunding: Tapping the right crowd. Journal of Business Venturing, 29(5), 585-609.

Bentley, P.A., \& Franklin, M.A. (2013). Which international cultures favor disclosure of risk. International Journal of Business, Accounting, \& Finance, 7(2), 62-76.

Berger, A.N., Goldberg, L.G., \& White, L.J. (2001). The effects of dynamic changes in bank competition on the supply of small business credit. European Finance Review, 5, 115-139.

Berger, A.N., \& Udell, G.F. (1988). The economics of small business finance: The roles of private equity and debt markets in the financial growth cycle. Journal of Banking and Finance, 22, 613-673.

Berger, A.N., \& Udell, G.F. (2006). A more complete conceptual framework for SME finance. Journal of Banking \& Finance, 30(11), 2945-2966.

Berger, A.N., \& Udell, G.F. (2002). Small business credit availability and relationship lending: The importance of bank organisational structure. The Economic Journal, 112(477), F32-F53.

Berger, A.N., Udell, G.F., Acs, Z., Berlin, M., Bonaccorsi, E., Bonime, S., \& Carey, M. (1998). The effects of bank mergers and acquisitions on small business lending. Journal of Financial Economics, 50, 187-229.

Bertomeu, J., \& Cheynel, E. (2013). Toward a positive theory of disclosure regulation: In search of institutional foundations. Accounting Review, 88(3), 789-824.

Bisman, J., \& Goela, N. (2010). The small industries development bank of India: A retrospective on SME financing. Indian Journal of Economics \&Business, 9(4), 803-820.

Blaseg, D., \& Koetter, M. (2015). Friend or foe? Crowdfunding versus credit when banks are stressed. IWH Discussion Papers, 8.

Borbás, L. (2015). The Role of SMEs in the European entrepreneurship policy. Volume of Management, Enterprise and Benchmarking in the 21st Century II, pp. 71-88.

Carvalho, N., \& Yordanova, Z. (2018). Why say no to innovation? Evidence from industrial SMEs in European Union. Journal of Technology Management and Innovation, 13(2), 43-56.

Chai, N., Wu, B., Yang, W., \& Shi, B. (2019). A multicriteria approach for modeling small enterprise credit rating: Evidence from China. Emerging Markets Finance and Trade, 55(11), 2523-2543.

Chand, O., \& Parmar, K.K. (2018). Strategic analysis of constraints in micro, Small and medium enterprises financing by banks. International Journal of Research in Commerce \& Management, 9(3), 4-7.

Chen, T.Y., Chin, C.L., Wang, S., \& Yao, C. (2015). The effects of financial reporting on bank loan contracting in global markets: Evidence from mandatory IFRS Adoption. Journal of International Accounting Research In-Press, 14(2), 45-81.

Cheng, L., Liao, S., \& Zhang, H. (2013). The commitment effect versus information effect of disclosureevidence from smaller reporting companies. Accounting Review, 88(4), 1239-1263.

Chhabra, K.S., \& Pattanayak, J.K. (2014). Financial accounting practices among small enterprises: Issues and challenges. IUP Journal of Accounting Research \& Audit Practices, 13(3), 37-55.

Chow, L.M., Chau, G.K., \& Gray, S.J. (1995). Accounting reforms in China: Cultural constraints on implementation and development. Accounting and Business Research, 26(1), 29-49.

Darrough, M., \& Deng, M. (2019). The Role of accounting information in optimal debt contracts with informed lenders. The Accounting Review, 94(6), 165-200.

Davidson, G.T., Moloney, J., Brennan, B.F., \& Dumont, N.H.R. (2013). SEC proposes rules to implement crowdfunding exemptions: What factors will affect its success. Insights.

Distinguin, I., Hasan, I., \& Tarazi, A. (2010). The use of accounting data to predict bank financial distress in MENA countries. International Journal of Banking, Accounting and Finance, 2, 332-356.

Dong, Y., \& Men, C. (2014). SME financing in emerging markets: Firm characteristics, banking structure, and institutions. Emerging Markets Finance and Trade, 50(1), 120-149. 
Elamer, A.A., Ntim, C.G., Abdou, H.A., Zalata, A.M., \& Elmagrhi, M. (2019). The impact of multi-layer governance on bank risk disclosure in emerging markets: The case of Middle East and North Africa. Accounting Forum, 43(2), 246-281.

Emett, S.A. (2019). Investor reaction to disclosure of past performance and future plans. The Accounting Review, 94(5), 165-188.

Gassen, J. (2017). The effect of IFRS for SMEs on the financial reporting environment of private firms: An exploratory interview study. Accounting and Business Research, 47(5), 540-563.

Gu, Y., Filatotchev, I., Bell, R.G., \& Rasheed, A.A. (2019). Liability of foreignness in capital markets: Institutional distance and the cost of debt. Journal of Corporate Finance, 57, 142-160.

Hail, L., \& Serafeim, G. (2011). Consequences and institutional determinants of unregulated corporate financial statements: Evidence from embedded value reporting. Journal of Accounting Research, 49(2), 573-594.

Han, S., Kang, T., Salter, S., \& Yoo, Y.K. (2010). A cross-country study on the effects of national culture on earnings management. Journal of International Business Studies, 41(1), 123-141.

Harner, M.M. (2015). Are the small-and-medium-sized companies worth saving? American Bankruptcy Institute Journal, 34(7), 8.

Hart, O., Shleifer, A., \& Vishny, R.W. (1997). The proper scope of government: Theory and an application to prisons. Quarterly Journal of Economics, 112(4), 1127-1161.

Haselip, J., Desgain, D., \& Mackenzie, G. (2013). Financing energy SMEs in Ghana and Senegal: Outcomes, barriers, and prospects. Energy Policy, 65, 369-376.

Hoang, T.P.T., \& Phung, D.N. (2019). Leverage and investment: A view of prominent role of state ownership. International Journal of Banking, Accounting and Finance, 10(2).

Hofstede, G. (1983). National cultures in four dimensions: A research-based theory of cultural differences among nations. International Studies of Management \& Organization, 13(1-2), 46-74.

Hofstede, G., \& Bond, M.H. (1988). The Confucius connection: From cultural roots to economic growth. Organizational Dynamics, 16(4), 5-21.

Hope, K. (2003). Firm-level disclosures and the relative roles of culture and legal origin. Journal of International Financial Management and Accounting, 14(3), 218-248.

Hope, K., Thomas, W.B., \& Vyas, D. (2013). Financial reporting quality of U.S. private and public firms. Accounting Review, 88(5), 1715-1742.

Huang, J.L., Chiaburu, D.S., Zhang, X., Li, N., \& Grandey, A.A. (2015). Rising to the challenge: Deep acting is more beneficial when tasks are appraised as challenging. Journal of Applied Psychology, 100(5), 1398-1408.

Kanagaretnam, K., Lim, Y.C., \& Lobo, G.J. (2011). Effects of national culture on earnings quality of banks. Journal of International Business Studies, 42(6), 853-874.

Kanagaretnam, K., Lim, C.Y., \& Lobo, G.J. (2014). Influence of national culture on accounting conservatism and risk-taking in the banking industry. The Accounting Review, 89(3), 1115-1149.

Kira, A.R., \& He, Z. (2012). The impact of firm characteristics in access of financing by small and medium-sized enterprises in Tanzania. International Journal of Business and Management, 7(24).

Kuntchev, V., Ramallo, R., Rodriguez-Meza, J., \& Yang, J.S. (2013, October 20). What have we learned from the enterprise surveys regarding access to credit by SMEs? The World Bank, Financial and Private Sector Development, Enterprise Analysis Unit, 6670.

Lukacs, E. (2005). The economic role of SMEs in world economy, especially in Europe. European Integration Studies, Miskolc, 4(1), 3-12.

Luo, P., Wang, H., \& Yang, Z. (2016). Investment and financing for SMEs with a partial guarantee and jump risk. European Journal of Operational Research, 249(3), 1161-1168.

Madill, J.J., Feeney, L., Riding, A., \& Haines, G.H. (2002). Determinants of SME owners' satisfaction with their banking relationships: A Canadian study. International Journal of Bank Marketing, 20(2), 86-98.

Mollick, E. (2014). The dynamics of crowdfunding: An exploratory study. Journal of Business Venturing, $29,1-16$. 
Neagu, C. (2016). The importance and role of small and medium-sized businesses. Theoretical and Applied Economics, 23(3), 331-338.

O'Donohoe, S., Hanley, A., \& Lyons, C. (2008). Relationship banking within the Irish SME sector and its implications. The Irish Accounting Review, 15(2), 59-85.

Ogden, S., \& Clarke, J. (2005). Customer disclosures, impression management and the construction of legitimacy. Accounting, Auditing \& Accountability Journal, 18(3), 313-345.

Okafor, R.G. (2012). Financial management practices of small firms in Nigeria: Emerging task for the accountant. European Journal of Business and Management, 4(19), 159-169.

Parnell, J.A. (2015). Crisis management and strategic orientation in small and medium-sized enterprises (SMEs) in Peru, Mexico, and the United States. Journal of Contingencies and Crisis Management, 23(4), 221-233.

Pollack, J.M., Rutherford, W., \& Nagy, B.G. (2012). Preparedness and cognitive legitimacy as antecedents of new venture funding in televised business pitches. Entrepreneurship: Theory and Practice, 36(5), 915-939.

Rao, P., Kumar, S., \& Madhavan, V. (2019). A study on factors driving the capital structure decisions of small and medium enterprises (SMEs) in India. IIMB Management Review, 31(1), 37-50.

Saliya, C.A., \& Jayasinghe, K. (2016). Creating and reinforcing discrimination: The controversial role of accounting in bank lending. Accounting Forum, 40(4), 235-250.

Salter, S.B., Kang, T., Gotti, G., \& Doupnik, T.S. (2013). The role of social values, accounting values and institutions in determining accounting conservatism. Management International Review, 53(4), 607-632.

Salter, S.B., \& Niswander, F. (1995). Cultural influence on the development of accounting systems internationally: A test of Gray's (1988) theory. Journal of International Business Studies, 26(2), 379-397.

Saparito, P.A., Chen, C.C., \& Sapienza, H.J. (2004). The role of relational trust in bank-small firm relationships. Academy of Management Journal, 47(3), 400-410.

Sapienza, P. (2004). The effects of government ownership on bank lending. Journal of Financial Economics, 72(2), 357-384.

Sharifi, O. (2014). Financial risk management for small and medium sized enterprises (SMES). International Journal of Information, Business \& Management, 6(2), 82-94.

Thiaw, N. (2019). Bringing global finance to small businesses. International Trade Forum, 2, $22-23$.

Tirole, J. (1994). The internal organization of governments. Oxford Economic Papers, 46(1), 1-29.

Tsakumis, G.T. (2007). The influence of culture on accountants' application of financial reporting rules. Abacus, 43(1), 27-48.

Verrecchia, R.E. (1999). Disclosure and the cost of capital: A discussion. Journal of Accounting and Economics, 26(1-3), 271-283.

Wellalage, N.H., \& Locke, S. (2016). Informality and credit constraints: Evidence from Sub-Saharan African MSEs. Applied Economics, 48(29), 2756-2770.

Wellalage, N.H., Locke, S., \& Samujh, H. (2019). Corruption, gender and credit constraints: Evidence from South Asian SMEs. Journal of Business Ethics, 159(1), 267-280.

Wu, J., Song, J., \& Zeng, C. (2008). An empirical evidence of small business financing in China. Management Research News, 31, 959-975.

Xiao, L., \& North, D. (2012). Institutional Transition and the Financing of High-Tech SMEs in China: A Longitudinal Perspective. Venture Capital, 14(4), 269-287.

Yang, A., Li, K., Bai, G., \& Guangbin, B. (2013). Market Efficiency of Collective Bonds for Small- and Medium-Sized Enterprises in China. The Chinese Economy, 46(6), 67-79.

Zheng, X., El Ghoul, S., Guedhami, O., \& Kwok, C.C.Y. (2013). Collectivism and corruption in bank lending. Journal of International Business Studies, 44(4), 363-390. 